\title{
Surface temperature of bitumen sheets in the flat roof structure
}

\author{
Jan Plachý1,*, and Jana Vysoká ${ }^{1}$ \\ ${ }^{1}$ The Institute of Technology and Business in České Budějovice, Okružní 10, 37001 České \\ Budějovice
}

\begin{abstract}
This paper deals with the surface temperature problem of flat roofs, where bitumen sheets are used as the final waterproofing layer. Currently it is possible to find defects due to the high surface temperature of the waterproofing layer on flat roofs. The result of such a high surface temperature is, for example, the release of bitumen sheets and the sublimation of the thermal insulation from foamed polystyrene. The paper focuses on the influence of the type, the color of the sprinkling and the type of background on the surface temperature. The aim of this paper is to determine the surface temperature of bitumen sheets based on the experimental measurement depending on the type and the colour of the surface. Measurements were made during warm summer days. Samples of bitumen sheets with green, grey, blue-grey, red, white and black-grey sprinkling were used. Concrete and foamed polystyrene were used as a background under bitumen sheets.
\end{abstract}

\section{Introduction}

This paper focuses on the surface temperature of waterproofing of bitumen sheets in flat roof compositions with a classical order of layers without the influence of sunlight reflection. In the composition of the classical order of layers, where the waterproofing is above the thermal insulation layer, bitumen sheets are directly exposed to sunlight.

High surface temperature is one of the causes of faults on flat roofs with a waterproofing coating. These failures are manifested, for example, by the release of joints and the sublimation of the thermal insulation from foamed polystyrene. As a result of the solar radiation, the temperature of bitumen sheets in the roof structures increases. Due to high temperatures, the dimensional stability of bitumen sheets is impaired. Bitumen sheets with polyester support are shrinking. This shrinkage occurred due to the pre-stressing that was introduced into the liner during the manufacturing process. Previously the topic of the surface temperature was analysed by authors for example [1], [2] on the European level, for example [3].

The surface temperature of bitumen sheets is mainly influenced by:

1. properties of bitumen sheets surface (emissivity, reflection),

2. substrate (thermal capacity),

\footnotetext{
* Corresponding author: plachy@mail.vstecb.cz
} 
3. ambient (air) temperature,

4. ambient radiation,

5. air flow and humidity.

In terms of surface properties of bitumen sheets, the scatter material, the particle size of the sprinkle, the sprinkling rate and colour are important for the solar reflectance and the surface emissivity of bitumen sheets. The most commonly used surface treatment of bitumen sheets is a coarse-grained or fine-grained mineral dispersion in the form of siliceous sand or slate. Another option is the ceramic sprinkle.

The aim of this paper is to find out which maximum temperatures are reached on the surface of bitumen sheets in terms of the type and colour of the sprinkle, whether this temperature approaches the value of $80^{\circ} \mathrm{C}$. This value is the limit guaranteed by producers of foamed polystyrene for its stability [4]. The same temperature is then used for bitumen sheets during the dimensional stability test according to EN 13707 [5], EN 1107-1 [6]. Thus, it is possible to pronounce hypothesis that the surface temperature of bitumen sheets does not exceed the value of $80{ }^{\circ} \mathrm{C}$. The temperature range between the maximum temperatures in terms of the colour and type of sprinkling will be more than $10^{\circ} \mathrm{C}$. The lowest temperatures will be achieved in bright colours and the highest temperatures in dark colours.

\section{Material and methods of testing}

One of possible increasing of the temperature of bitumen sheets can be the upper surface treatment with the coarse-grained sprinkling. To determine the specific numerical values of the maximum temperatures on the surface of bitumen sheets for a certain type of the surface and the colouring of the dispersion, experimental measurements were made. The measurement has shown how great temperature differences occur on the surface of bitumen sheets.

\subsection{Material}

\subsubsection{Samples of bitumen sheets}

Bitumen sheets produced in TechnoNIKOL were selected for the experimental part. The top modified sheet was chosen with thickness of $4.2 \mathrm{~mm}$ with coarse-grained slate $(80 \%$ in the fraction of $0.5-2.0 \mathrm{~mm}$ ) in the colours red, green, grey, blue-grey, white and redyellow, see Figure 1. For the comparison of achieved temperatures, bitumen sheets of black and grey colour with fine sprinkle (slate) and siliceous sand ( $80 \%$ in the fraction $0.18-$ $0.63 \mathrm{~mm}$ ) were also measured. These bitumen sheets are used as a base under the coarsegrained sheet. See Figure 2.

Samples of bitumen sheets of size $200 \times 200 \mathrm{~mm}$ were loosely laid on a mineral wool base $(\lambda \mathrm{D}=0.037 \mathrm{~W} / \mathrm{mK})$ with thickness of $100 \mathrm{~mm}$. Samples on the substrate were laid on a flat roof of bitumen sheets and were directly exposed to sunlight without any further reflection of the sunrays. 


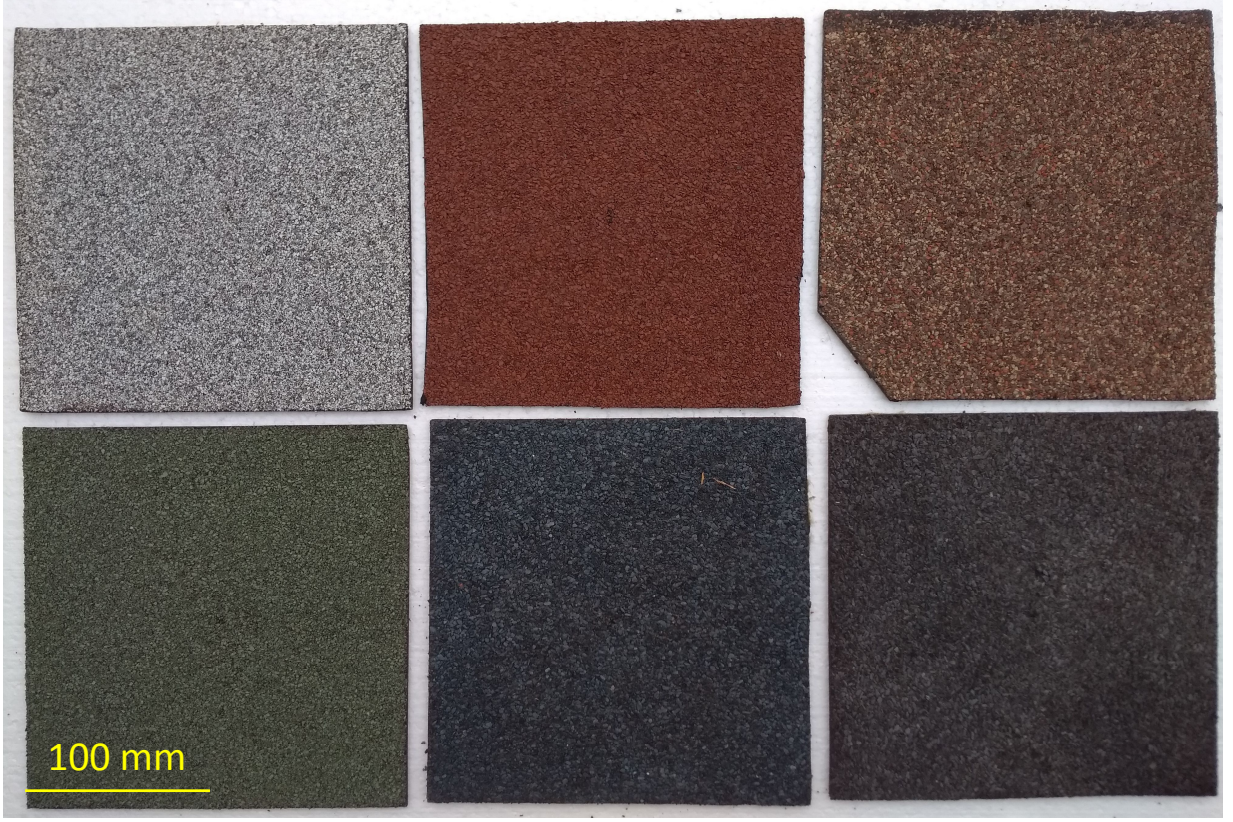

Fig. 1. Bitumen sheets with coarse grain. Legend: $\mathrm{A}$ - white, $\mathrm{B}$ - red, $\mathrm{C}-$ red-yellow, D - green, E blue-gray, F - gray. Source: author.

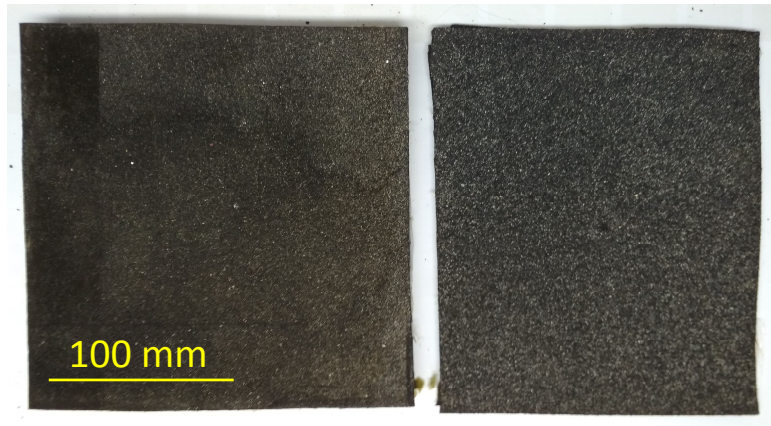

Fig. 2. Bitumen sheets with fine grain. Legend: A - micro slate, B - quartz sand. Source: author.

\subsubsection{Machines}

Two methods were used to measure the temperature: contact and contactless. Non-contact method using the Voltcraft IR-650-12D IR thermometer with a temperature resolution of $0.1{ }^{\circ} \mathrm{C}$ and a basic accuracy of $\pm 3{ }^{\circ} \mathrm{C}$. The set emissivity of 0.92 corresponds to the behaviour of the surface of the bitumen strips with IR spectrum scattering.

Contact method was used with universal measuring instrument ALMEMO 2590-4 with thermocouple TYP K-T190-1 with the temperature resolution of $0.1{ }^{\circ} \mathrm{C}$ and the measurement accuracy of $0.03 \%$, see Figure 3. 


\subsection{Methods of testing}

Samples of bitumen sheets were placed on a classic flat lean-to roof with $5{ }^{\circ} \mathrm{C}$ inclination of southeast orientation. From the point of view of air flow, the roof is located in a normal landscape on a sheltered, stand-alone building at an altitude of about $2.0 \mathrm{~m}$ above the terrain at an altitude of about $425 \mathrm{~m}$ above sea level in the village Planá nad Lužnicí (GPS: 49.3630811N, 14.7196306E). Air temperature measurements were made about $15 \mathrm{~mm}$ above the mineral wool base using the thermocouple TyP K, see Figure 4. In order to partially eliminate the influence of the wind, a low covering was formed around the samples. See Figure 3.

The measurements were carried out during the summer between August 3 and August 8 in 2018. Due to the availability of individual devices, the measurements were not performed in parallel. The continuous method was used from August 3 and August 5 in 2018, the contact method from August 6 and August 8 in 2018. In the long-term view, summer 2018 can be considered the warmest in 244 year history of temperature monitoring in the Czech Republic [7].

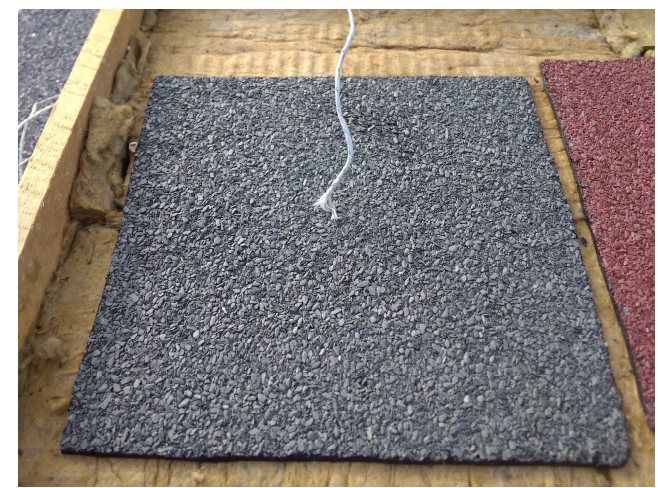

Fig. 3. Contact measurement of surface temperature and solution of the edge of the substrate. Source: author.

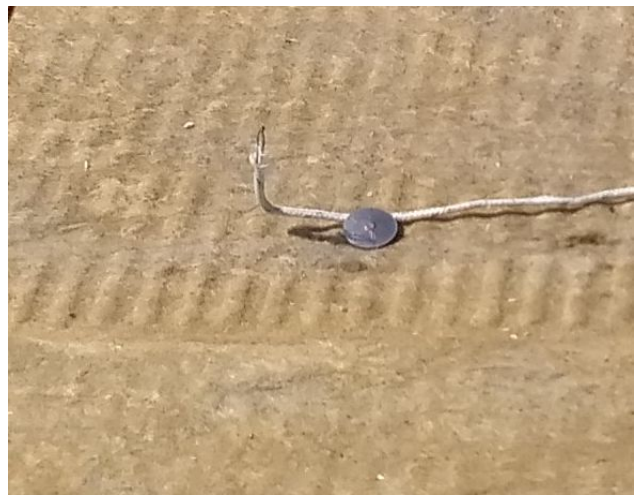

Fig. 4. The air temperature measurement. Source: author. 


\section{Results}

The results of both methods are shown in Table 1. Maximum surface temperatures were recorded at an air temperature on August 8,2018 at $43.8{ }^{\circ} \mathrm{C}$. The maximum temperature at the measuring station of the Czech Hydrometeorological Institute (CHMU) in this day in the Czech Republic was measured in Dobrichovice in the value of $36.4{ }^{\circ} \mathrm{C}$ [8].

Table 1. A survey of measured maximum temperature values for bitumen sheets during a warm summer day depending on the surface colour. Legend: HMP - coarse-grained mineral spread, JMP fine-grained mineral spraying. Source: author.

\begin{tabular}{|c|c|c|c|}
\hline \multirow{2}{*}{ Colour } & \multirow{2}{*}{$\begin{array}{c}\text { Type of } \\
\text { spreading }\end{array}$} & $\begin{array}{c}\text { Non-contact method } \\
\mathbf{( 3 - 5 . 8 . 2 0 1 8})\end{array}$ & $\begin{array}{c}\text { Contact method } \\
\mathbf{( 6 - 8 . 8 . 2 0 1 8})\end{array}$ \\
\cline { 3 - 4 } & & {$\left[{ }^{\circ} \mathrm{C}\right]$} & {$\left[{ }^{\circ} \mathrm{C}\right]$} \\
\hline green & HMP & 73.8 & 71.1 \\
\hline grey & HMP & 73.3 & 75.3 \\
\hline red & HMP & 76.8 & 72.3 \\
\hline blue-grey & HMP & 74.2 & 70.9 \\
\hline white & HMP & 69.4 & 70.0 \\
\hline yellow-red & HMP & 70.5 & 67.6 \\
\hline slate & JMP & 74.4 & 71.8 \\
\hline sand & JMP & 74.7 & 73.1 \\
\hline
\end{tabular}

\section{Discussion}

The maximum temperature of $80{ }^{\circ} \mathrm{C}$ was not achieved on any surface using any one of the measurement methods. Therefore hypothesis has been confirmed.

In the case of the non-contact method, temperatures ranged from $69.4{ }^{\circ} \mathrm{C}$ to $76.8{ }^{\circ} \mathrm{C}$. The temperature range is therefore $7.4^{\circ} \mathrm{C}$. In the case of the contact method, temperatures ranged from $67.6^{\circ} \mathrm{C}$ to $75.3{ }^{\circ} \mathrm{C}$, the temperature range is $7.7^{\circ} \mathrm{C}$. Therefore the hypothesis of a maximum temperature range of more than $10^{\circ} \mathrm{C}$ was not confirmed.

The results of both methods differ in the order of maximum temperatures depending on the colour of the sprinkle. Maximum temperatures can be divided into three intervals for both measurement methods. Three intervals were selected for the accuracy of a non-contact method. One interval was approximately $2.5^{\circ} \mathrm{C}$. See Table 2 .

Table 2. A survey of measured maximum temperature values for bitumen sheets during a warm summer day depending on the surface colour. Source: author.

\begin{tabular}{|l|c|c|c|}
\hline $\begin{array}{l}\text { Surface temperature } \\
\text { measurement method }\end{array}$ & Interval A $\mathbf{~}^{\circ} \mathbf{C} \mathbf{]}$ & Interval $\mathbf{B}\left[{ }^{\circ} \mathbf{C} \mathbf{]}\right.$ & Interval $\mathbf{C}\left[{ }^{\circ} \mathbf{C}\right]$ \\
\hline Non contact method & $76.80-74.33$ & $74.32-71.87$ & $71.86-69.40$ \\
\cline { 2 - 4 } & red, slate, sand & $\begin{array}{c}\text { green, grey, blue- } \\
\text { grey, }\end{array}$ & white, yellow-red \\
\hline Contact method & $75.30-72.73$ & $72.72-70.17$ & $70.16-67.60$ \\
\cline { 2 - 4 } & grey, sand & $\begin{array}{c}\text { green, red, blue- grey, } \\
\text { slate }\end{array}$ & white, yellow-red, \\
\hline
\end{tabular}


For both methods, it was confirmed that the highest temperatures were achieved on bitumen sheets with treatment in the form of sand, although no maximum temperature was measured on the sheet. The highest temperatures were in dark colours: red, grey, lower temperatures on green and blue-grey and the lowest on white and yellow-red. The low temperature in the yellow-red colour is especially surprising. The hypothesis was therefore confirmed.

\section{Conclusion}

The results show that the colour of the sprinkle has, in practical terms, a considerable influence on the surface temperature of bitumen sheets and thus their aging rate. From the selection of the colour range of the sprinkle, the light colours should be preferred to dark colours such as red. Above all, combined with the reflection of the sunlight, the temperature can be exceeded in the long run by about $80^{\circ} \mathrm{C}$.

The next phase of the research will be focused on the influence of the substrate comparison of the temperature on the waterproofing layer from one and more bitumen sheets.

\section{References}

1. J. Plachý. Bitumen sheet joints under the influence of temperature and time in the composition of single-membrane roof,. (Brno University of Technology, Faculty of civil engineering, Brno, 2005)

2. O. Žídek, A. Žák. Měrení teplot ovlivněných odrazem slunečního záření od prosklených ploch v polystyrenu na střeše s povlakovou hydroizolací. (DEKTRADE, Praha, 2017). Available on https://www.dekpartner.cz/aktuality/detail/224

3. CH. J. Sarkis, O. M. Raich, J. L. Zamora Meastre. Energy Procedia, 115, 451-462 (2017)

4. K. Chaloupka, P. Rydlo. Izolační praxe 3. Ploché střechy a pěnový polystyren. Sdružení EPS ČR, (2016). Available on http://www.epscr.cz/obj/1145/IP 3 Ploche strechy a penovy polystyren.pdf

5. C̆SN EN 13707. Flexible sheets for waterproofing - Reinforced bitumen sheets for roof waterproofing - Definitions and characteristics (2014)

6. Č CN EN 1107-1. Flexible sheets for waterproofing - Part 1: Bitumen sheets for roof waterproofing - Bitumen sheets for roof waterproofing - Determination of dimensional stability (2000)

7. CHMU, Available on http://www.infomet.cz/index.php?id= read\&idd=1536178479 (2018a)

8. CHMU, Available on http://portal.chmi.cz/ files/portal/docs/ poboc/OS/OMK/mapy/prohlizec.html?map =TMA $(2018 \mathrm{~b})$ 